\title{
Clinical, cardiopulmonary and haemocytological effects of xylazine in goats after acute exposure to different environmental temperature and humidity conditions
}

\author{
E G M Mogoa ${ }^{a^{*}}$, G F Stegmann ${ }^{a}$, A J Guthrie ${ }^{b}$ and G E Swan ${ }^{c}$
}

\begin{abstract}
This study was carried out to assess the influence of xylazine administration on clinical, cardiopulmonary and haemocytological variables after acute exposure to different environmental conditions. Xylazine hydrochloride was administered intravenously at $0.1 \mathrm{mg} / \mathrm{kg}$ body mass to 6 clinically healthy, castrated male goats. All animals were exposed for 60 min to 3 sets of climatic conditions: $14{ }^{\circ} \mathrm{C}, 33 \%$ relative humidity; $24{ }^{\circ} \mathrm{C}, 55 \% \mathrm{RH}$, and $34{ }^{\circ} \mathrm{C}, 65 \% \mathrm{RH}$. The variables that were measured for a period of $60 \mathrm{~min}$ after xylazine administration were sedation, analgesia, salivation, urination, ventilation rate, heart-rate, mean arterial blood pressure, oesophageal temperature, haematocrit, mean corpuscular volume and mean corpuscular haemoglobin concentration. Xylazine induced sedation, analgesia, salivation and urination independently of the 3 environmental conditions. Environment had no influence on the onset, duration and recovery from sedation. In the $14{ }^{\circ} \mathrm{C}$ environment, xylazine resulted in a significant decrease in ventilation and heart-rate from baseline values. Significant changes in mean arterial blood pressure, haemoglobin concentration, mean corpuscular volume, haematocrit and red cell count were observed in the 3 environments. Total plasma protein was significantly altered at $24^{\circ} \mathrm{C}$ and $34^{\circ} \mathrm{C}$. Acute exposure of goats to different environmental conditions had no significant influence on the clinical, cardiopulmonary and haemocytological variables. Physiological changes induced by xylazine were therefore independent of the environment.
\end{abstract}

Key words: caprine, cardiopulmonary, haematology, sedation, temperature, xylazine.

Mogoa E G M, Stegmann G F, Guthrie A J, Swan G E. Clinical, cardiopulmonary and haemocytological effects of xylazine in goats after acute exposure to different environmental temperature and humidity conditions. Journal of the South A frican Veterinary A ssociation (2000) 71(3): 153-159 (En.). Department of Companion Animal Surgery, Faculty of Veterinary Science, University of Pretoria. Private Bag X04, Onderstepoort, 0110 South Africa.

\section{INTRODUCTION}

Xylazine, pharmacologically classified as an analgesic as well as a sedative and skeletal muscle relaxant ${ }^{6}$, is widely used in biological research and veterinary medicine ${ }^{18,22}$. The drug induces a number of physiological and pharmacological changes in the speciesin which its usehas been studied. The cardiopulmonary and haematological effects of xylazine have been investigated in several animal species including goats $1,5,12,23,24,28,32,35$, cattle $^{3,7,13}$, sheep ${ }^{4,9}$, cats $^{12}$, horses ${ }^{11,17}$, dogs $^{21}$, and donkeys ${ }^{27}$.

Xylazine, when injected intravenously in animals, induces hypotension,

\footnotetext{
aDepartment of Companion Animal Surgery, Faculty of Veterinary Science, University of Pretoria, Private Bag X04, Onderstepoort, 0110 South Africa.

${ }^{b}$ Equine Research Centre, Faculty of Veterinary Science, University of Pretoria.

'Department of Pharmacology and Toxicology, Faculty of Veterinary Science, University of Pretoria.

${ }^{*}$ Present address: Department of Clinical Studies, Faculty of Veterinary Medicine, University of Nairobi.

Received: November 1999. Accepted: July 2000.
}

bradycardia, heart block, ventilatory depression and, in ruminants, marked salivation $^{6}$. In horses ${ }^{11}$, dogs ${ }^{21}$ and sheep ${ }^{4}$, when injected intravenously, xylazine causespartial cardiacconduction blockade with arrhythmia and bradycardia. In ponies, intravenous xylazine produces sino-atrial (SA) block, transient atrioventricular (AV) block and bradycardia within 1 min of injection ${ }^{17}$. A study in heifers revealed that the recovery period, duration of salivation and sedation following xylazine administration were longer in animals acclimatised to hot, humid conditions than in animals under thermoneutral conditions ${ }^{15}$. To our knowledge, the influence of different environmental temperature and humidity conditions on the clinical, cardiopulmonary and haemocytological effects of xylazine in goats has not been described. Thepurposeof thisstudy wasthereforeto investigate these effects in goats under differentenvironmental temperatureand humidity conditions.

\section{MATERIALS AND METHODS}

Six adult, clinically healthy, indigenous (nondescript African breed), castrated male goats, weighing between 21.0 and $34.0 \mathrm{~kg}$ with a mean ( \pm SEM) mass of $28.2 \pm 1.0 \mathrm{~kg}$ were used. They were housed indoors in individual crates and fed a diet of lucerne, hay and water, which were provided ad libitum. At least 1 month before commencement of the study, the carotid artery was relocated under hal othane anaesthesia to a subcutaneous position in all the animals. The protocol for this study was approved by the Ethics and Research Committees of the Faculty of Veterinary Science, University of Pretoria.

A single group, 3-phase repeatedmeasures design was used to study the effect of environmental temperature and humidity on some clinical, cardiopulmonary and haemocytological effects of xylazine in 6 goats. These effects were monitored repeatedly for a period of 60 min in the goats during low, medium and high temperature and humidity exposure treatment phases. A washout period of at least 7 days was allowed between treatment phases. The experiments in this study were conducted in temperature and humidity-controlled environments. Phase 1 of the study was conducted in the medium temperature and humidity environment with room temperature set at $24 \pm 1{ }^{\circ} \mathrm{C}$ and a relative humidity of $55 \pm 1 \%$. Phase 2 of thestudy was conducted in the high temperature and humidity environment with room temperature set at $34 \pm 1^{\circ} \mathrm{C}$ and a relative humidity of $65 \pm 1 \%$. Phase 3 of thestudy was conducted in the low temperature and humidity environment with the room temperature set at $14 \pm 1{ }^{\circ} \mathrm{C}$ and a relative humidity of $33 \pm 1 \%$. The temperature and humidity were set $12 \mathrm{~h}$ before any experiment began to ensure uniformity of conditions in the rooms. Between experiments, the goats were housed and fed in individual crates in housing premises without temperature and humidity control. Before any experiment was carried out, the goats were starved for $24 \mathrm{~h}$ and water was withheld 
for $12 \mathrm{~h}$. On the day of the experiment, each goat was weighed and taken into a preparation room adjacent to the temperature- and humidity-controlled room.

In the preparation room, the goats were restrained in lateral recumbency on a waterproof foam mattress. The jugular furrows on both sides of the neck were surgically prepared. An $18 \mathrm{G}$ intravenous catheter (Jelco ${ }^{\circledR}$, Critikon) was percutaneously introduced into the left jugular vein, flushed with heparinised saline, capped and sutured to the skin with nylon No. 2/0 (Ethilon) sutures. Another $20 \mathrm{G}$ catheter (M edican ${ }^{\circledR}$, Medical Specialities) was percutaneously introduced into the subcutaneously situated right carotid artery, flushed with heparinised saline, capped and sutured to the skin with nylon sutures. The animals were then transferred to the temperature- and humidity-controlled rooms. Lateral recumbency was maintained. A multiparameter physiological monitor was used to monitor the mean arterial blood pressure and heart-rate (Propaq ${ }^{\circledR}$ 104EL, Protocol Systems, Oregon, USA). A calibrated strain-gaugeblood pressure transducer was connected to the carotid artery via non-compliant tubing and a 3-way stopcock. The zero-point for the straingauge blood pressure transducer was taken at the level of the sternum. After a stabilisation period of 10-15 min, baseline readings were recorded. Xylazine hydrochloride (Rompun ${ }^{\circledR}$, Bayer Animal Health, I sando, South Africa) was injected intravenously at a dose of $0.1 \mathrm{mg} / \mathrm{kg}$ body mass over a period of $60 \mathrm{sec}$. Thetemperature probe was introduced via the ventral nasal meatusto the proximal oesophagus. The ventilation rate was determined using a capnograph (N ormocap 200, Datex Instrumentarium Corporation, Helsinki), or by counting the thoracic excursions over a 1-min period. The ventilation rate, heart-rate, and mean arterial blood pressures were recorded at 'time zero' (baseline) and at 5, 15, 30, 45, and $60 \mathrm{~min}$ post-xylazine injection. Venous blood for the determination of haemoglobin concentration, red cell count, white cell count, haematocrit, mean corpuscular haemoglobin concentration, mean corpuscular volume and total protein were drawn from the jugular vein into EDTA tubes at 'time zero' and 15, 30, and $60 \mathrm{~min}$ post-xylazineinjection. These determinations were made within $6 \mathrm{~h}$ of sample collection. All cell counts and blood cell parameters were determined using a System 9000 Diff Model Automated Cell Counter (Serono Diagnostics, Pennsylvania, USA). Total plasma protein was determined using an RA-1000 Analyzer (Technicon Instruments Corporation,
New York, USA) based on the Biuret reaction of Weichselbaum and as described by Skeggs and Hochstrasser ${ }^{39}$. Other variables evaluated over the entire monitoring period weresedation, analgesia, salivation, muscle relaxation and recovery time. Sedation was assessed by observing for drooping of the upper eyelidsand protrusion of thetongue. Analgesia was assessed by the response of the goatsto needleprickson theflank, thorax, coronary band and manual pinching of the interdigital skin. Muscle relaxation was evaluated according to the muscle tone of the mandible and uppermost fore and hind limbs during passive flexing and extending. Recovery time was considered to be the time when the animals were able to stand unassisted.

\section{Data analysis}

The data were analysed on a personal computer equipped with statistical software (Sigma Stat 2.0, Jandel Scientific Software ${ }^{\circledR}$, Jandel Corporation, San Rafael, California, USA). Results are presented as mean and standard error of the mean. To test for significance of the effect of treatment over time as well as for differences among treatments between groups, data collected over time were analysed using a 2-way repeatedmeasures ANOVA. When a significant effect of treatment was observed, comparisons between treatments were performed using 1-way AN OVA for repeated measures followed by Bonferroni's t-test to examine for least significant difference. Significant changes with time within any group were also analysed using 1-way ANOVA for repeated measures followed by Bonferroni's t-test to examine deviation from control (baseline, 'time zero') values. Where the data were either not normally distributed or the equal variance test failed, they were analysed using Friedman repeated-measures ANOVA on ranks followed by Dunnett's method to examine deviationsfrom baseline or 'time zero' (control) values. $\mathrm{P}<0.05$ was considered significant.

\section{RESULTS}

\section{Clinical and behavioural effects}

Oesophageal temperature decreased from $39.2 \pm 0.2^{\circ} \mathrm{C}$ to $38.6 \pm 0.2^{\circ} \mathrm{C}$ at $24^{\circ} \mathrm{C}$ environment, increased from $39.3 \pm 0.1^{\circ} \mathrm{C}$ to $39.8 \pm 0.1{ }^{\circ} \mathrm{C}$ at the $34^{\circ} \mathrm{C}$ environment, and decreased from $39.5 \pm 0.1{ }^{\circ} \mathrm{C}$ to 38.0 $\pm 0.2{ }^{\circ} \mathrm{C}$ at the $14{ }^{\circ} \mathrm{C}$ environment. The latter decrease was significantly different from baseline.

Under all environmental conditions, xylazine administration to the goats caused initial excitement and restlessness characterised by bleating, groaning, grunting and limb movements that lasted from 1 to $5 \mathrm{~min}$. Nystagmus was also evident during this period. This was followed by a period of calm and the animals remained sedated for the next 25 to $30 \mathrm{~min}$, with occasional bleating and tail switching observed in some of the goats. Signs of recovery evidenced by leg movements and raising of the head occurred within 40 to 50 min following xylazine administration. Attheend of themonitoring period, the jugular vein and arterial indwelling catheters and theoesophageal thermometer probe were removed and the animals were left undisturbed to rise on their own. The mean times required to rise unaided were $73.8 \pm 4.9,70.5 \pm 0.8$, and $68.0 \pm 1.0 \mathrm{~min}$ from the time of xylazine administration in the 24,34 , and $14{ }^{\circ} \mathrm{C}$ environments respectively. There was no significant difference in the time they took to stand under the different sets of environmental conditions. On standing, all the animals had a stable gait, ate and drank water immediately without any difficulty.

Following intravenous administration of xylazine, salivation started at $6.3 \pm 0.8$, $5.7 \pm 1.4$, and $6.5 \pm 1.2 \mathrm{~min}$ in the 24,34 and $14{ }^{\circ} \mathrm{C}$ environments respectively. Although the amount of saliva was small at the beginning, it became copious in the following minutes and then subsided to very small amounts. The duration of salivation was $45.7 \pm 2.0,45.2 \pm 4.6$, and 44.3 $\pm 3.1 \mathrm{~min}$ in the 24,34 , and $14{ }^{\circ} \mathrm{C}$ environments respectively. Therewereno significant differences in the time salivation started or the duration of salivation under the different environmental conditions.

Following administration of xylazine to the goats, insensitivity of the abdominal and thoracic skin to pin-pricks was present starting at $7.4 \pm 1.5 \mathrm{~min}$ in the $24^{\circ} \mathrm{C}$ environment and the duration of analgesia was $40.0 \pm 3.7 \mathrm{~min}$. In the $34^{\circ} \mathrm{C}$ environment, analgesia of the thorax and abdomen was present at $6.17 \pm 0.8 \mathrm{~min}$ that lasted for $43.8 \pm 3.9 \mathrm{~min}$. Theonset of analgesia was at $5.5 \pm 0.5$, and the duration was $39.5 \pm 2.2 \mathrm{~min}$ in the $14{ }^{\circ} \mathrm{C}$ environment. In all cases, there was no analgesia distal to the coronary band. The analgesia of the abdominal skin persisted longer than that of the thoracic wall skin. The onset and duration of analgesia were not statistically different under the different environmental conditions.

Xylazine induced voiding of large amounts of urine under all environmental conditions after $21.0 \pm 1.9 \mathrm{~min}$ and also after $69.6 \pm 3.4 \mathrm{~min}$. Xylazine provided good muscle relaxation in all the goats under all conditions and this lasted during the 25 to 30 min of sedation. 


\section{Cardiopulmonary and haemocyto-} logical effects

The trend in heart-rate following intravenous injection of xylazine in the goats under all environmental conditions was similar (Fig. 1). Within the 1st minute following injection of the drug, half of the goats exhibited bradycardia and atrioventricular (AV) block, followed by tachycardia. Bradycardia alternated with tachycardia in most of the goats during the first $5 \mathrm{~min}$ after administration of xylazine, and this persisted for up to 10 min in some goats. Mean heart-rates declined in all 3 environments for the rest of the monitoring period. The heart-rates had not returned to baseline values at the end of the monitoring period. The mean heart-rate for the goats exposed to $24^{\circ} \mathrm{C}$ decreased from $74.0 \pm 6.1$ beats $/ \mathrm{min}$ at 'time zero' to $63.0 \pm 6.0$ beats $/ \mathrm{min}$ at $30 \mathrm{~min}$ and declined further to $58.0 \pm 4.2$ beats/min at $60 \mathrm{~min}$ post-xylazine injection, a decrease of $22 \%$. In the $34^{\circ} \mathrm{C}$ environment, mean heart-rateincreased from baseline value of $76.5 \pm 3.9$ beats/min to $82.5 \pm 11.9$ at $5 \mathrm{~min}$ and then declined to $66.7 \pm 4.4$ beats $/ \mathrm{min}$ at $30 \mathrm{~min}$ and then further to $64.3 \pm 7.2$ beats $/ \mathrm{min}$ at $60 \mathrm{~min}$, a decline of $16 \%$. None of these changes were significant compared to baseline values. The mean heart-rates of goats in the $14{ }^{\circ} \mathrm{C}$ environment dedined from 85.0 \pm 10.9 beats $/ \mathrm{min}$ at timezero to $72.8 \pm 9.4$ at $30 \mathrm{~min}$ and then further to $60.0 \pm 3.2$ beats $/ \mathrm{min}$ at $60 \mathrm{~min}$, a decline of $29 \%$. Mean heart-rate 60 min post-xylazine injection in this group was significantly $(P<0.05)$ lower than the baseline value. There was marked individual variation in heart-rate under the different environmental conditions. Environmental conditions did not in general have a significant effect on heart-rate.

Mean arterial blood pressure (MAP) changes following injection of xylazine were similar under the 3 sets of environmental conditions (Fig. 2). Within 2 min of the injection of the drug, all goats developed arterial hypertension. In the $24^{\circ} \mathrm{C}$ environment, MAP rose from $16.1 \pm 0.5$ $\mathrm{kPa}$ at 'time zero' to $20.9 \pm 1.0$. In the 34 and $14{ }^{\circ} \mathrm{C}$ environments, MAP rose from $15.8 \pm 0.5$ and $14.9 \pm 0.5$ at 'time zero' to $18.7 \pm 0.2$ and $18.9 \pm 0.7 \mathrm{kPa}$ respectively. Thereafter the MAP started to decreaseto a minimum pressure at $15 \mathrm{~min}$ of $4.5 \mathrm{kPa}$ in the $24^{\circ} \mathrm{C}$ environment. In the 34 and $14{ }^{\circ} \mathrm{C}$ environments, maximum decrease in MAP of 5.3 and $4.3 \mathrm{kPa}$ were recorded at 5 min post-xylazine injection, respectively. Following the maximal decline, MAP started increasing in all 3 environments but had not returned to baseline values by the end of the 60-min monitoring period. The MAP valuesat 5, 15, 30, 45,

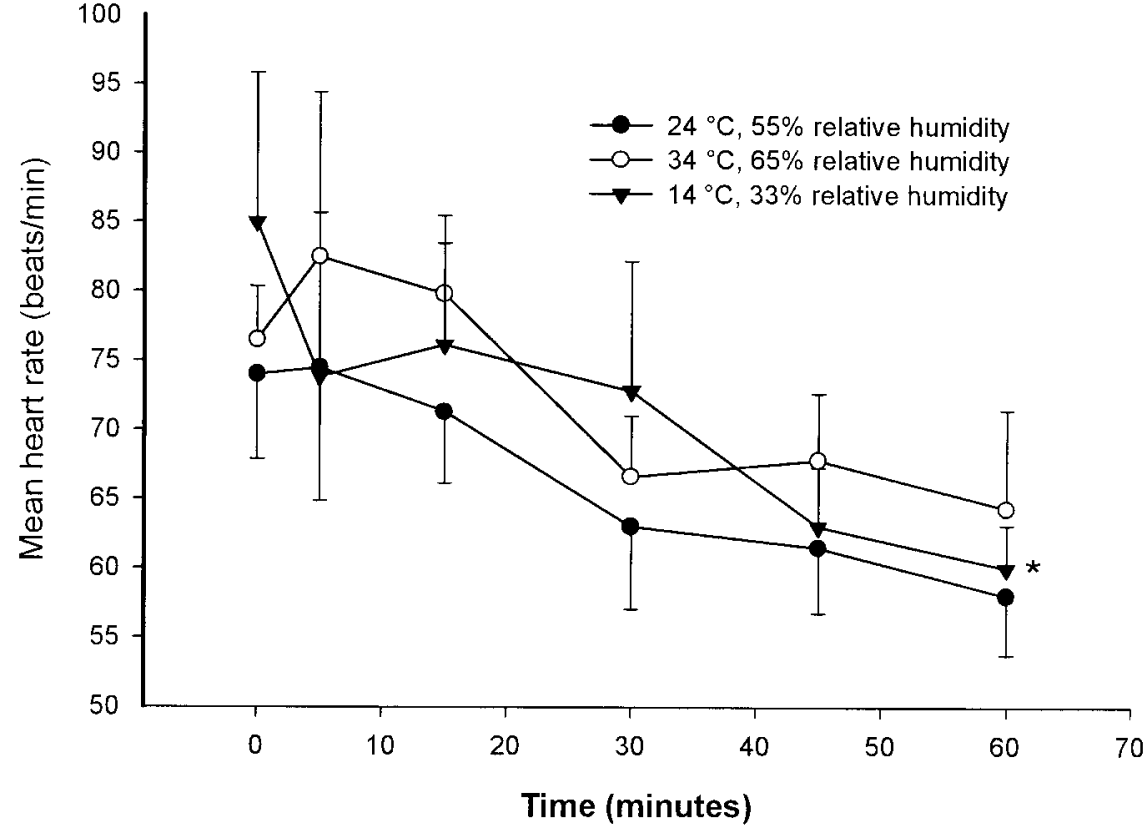

Fig. 1: Temporal changes (mean $\pm S E M)$ in heart-rate of goats following intravenous injection of $0.1 \mathrm{mg} / \mathbf{k g}$ xylazine under different environmental conditions. ${ }^{\star}$ Significantly $(P<0.05)$ different from values at time zero.

and 60 min post-xylazine injection were significantly $(P<0.05)$ lower than base linevaluesunder all 3sets of environmental conditions. There were no significant differences in mean arterial blood pressureattributableto the differencesin temperature and humidity in the 3 environments.

Xylazine resulted in clinically significant changes in ventilation rate under all environmental conditions. Within $5 \mathrm{~min}$ of drug administration, the goats exhibited apnoea that lasted up to $1 \mathrm{~min}$ in some goats. The apnoea alternated with irregular, laboured breathing, whilesome

goats showed open-mouth breathing and gasping for air. Therewas also cyanosis of the oral mucous membranes. For the rest of the monitoring period, the breathing pattern alternated between rapid, shallow breathing to deep and slow breathing as evidenced by the thoraco-abdominal movements. Regular breathing patterns were observed in most goats after 45 to $50 \mathrm{~min}$. Ventilation rate varied under the different environmental conditions. In the $24^{\circ} \mathrm{C}$ environment, the mean rate increased from the baseline of $28.7 \pm 3.2$ breaths/min to $31.5 \pm 7.0$ at $15 \mathrm{~min}$ and then decreased to $20.3 \pm 2.7$ breaths $/ \mathrm{min}$

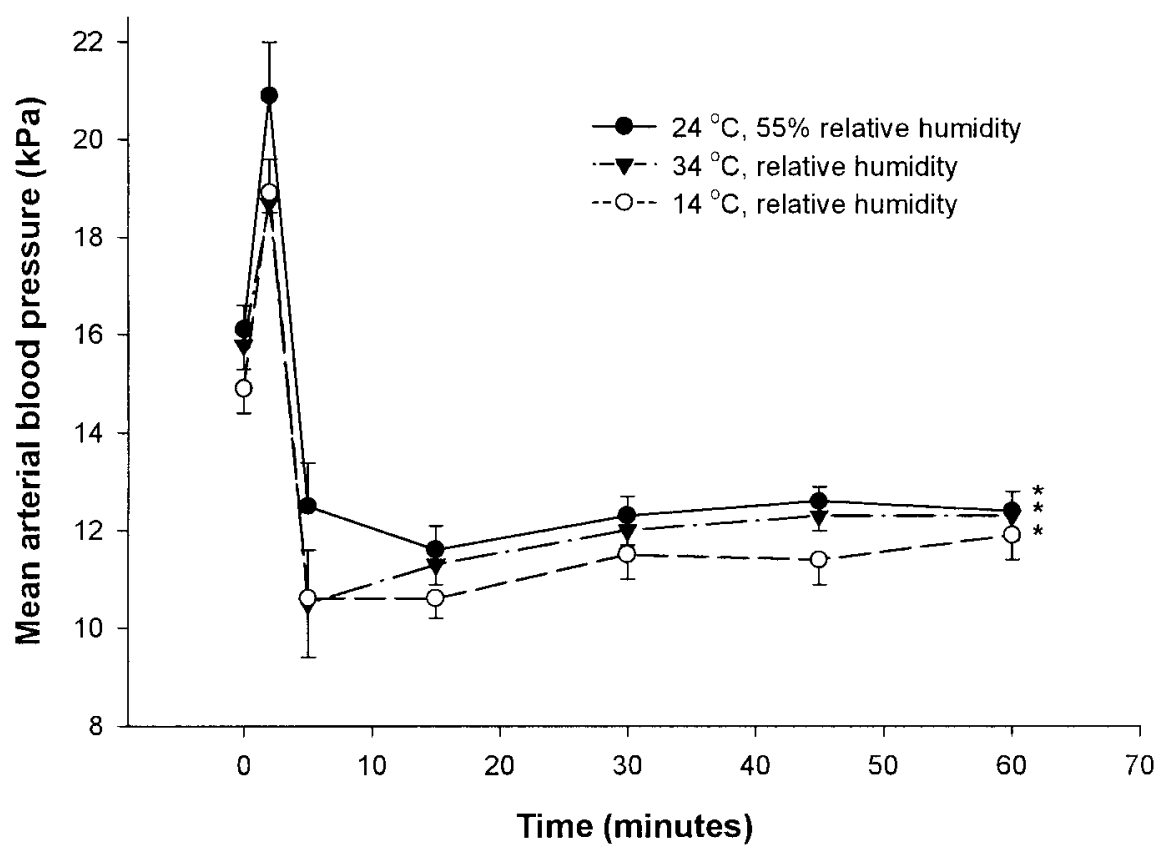

Fig. 2: Temporal changes (mean \pm SEM) in mean arterial blood pressure of goats following intravenous injection of $0.1 \mathrm{mg} / \mathbf{k g}$ xylazine under different environmental conditions. *Significantly $(P<0.05)$ different from values at time zero. 
Table 1: Changes in haemocytological variables (mean \pm SEM) in goats following intravenous injection of $0.1 \mathrm{mg} / \mathbf{k g} \mathbf{x y l a z i n e ~ u n d e r ~}$ different environmental conditions.

\begin{tabular}{|c|c|c|c|c|c|}
\hline \multirow[t]{2}{*}{ Variable } & \multirow[t]{2}{*}{ Temperature $\left({ }^{\circ} \mathrm{C}\right)$} & \multicolumn{4}{|c|}{ Time post-xylazine injection (min) } \\
\hline & & 0 & 15 & 30 & 60 \\
\hline $\mathrm{Hb}(\mathrm{g} / \mathrm{l})^{\mathrm{a}}$ & $\begin{array}{l}14 \\
24 \\
34\end{array}$ & $\begin{array}{l}106.3( \pm 2.9) \\
104.0( \pm 2.6) \\
104.2( \pm 4.8)\end{array}$ & $\begin{array}{l}94.8( \pm 3.1)^{\star} \\
90.3( \pm 7.8)^{\star} \\
88.2( \pm 1.5)^{\star}\end{array}$ & $\begin{array}{l}91.3( \pm 3.1)^{*} \\
87.9( \pm 2.9)^{*} \\
85.1( \pm 2.3)^{*}\end{array}$ & $\begin{array}{l}93.9( \pm 3.5)^{*} \\
89.4( \pm 3.1)^{\star} \\
88.7( \pm 3.4)^{\star}\end{array}$ \\
\hline $\operatorname{RCC}\left(\times 10^{12} / l\right)^{b}$ & $\begin{array}{l}14 \\
24 \\
34\end{array}$ & $\begin{array}{l}17.4( \pm 0.6) \\
17.3( \pm 0.5) \\
17.0( \pm 0.5)\end{array}$ & $\begin{array}{l}15.6( \pm 0.3)^{*} \\
15.3( \pm 0.4)^{\star} \\
14.8( \pm 0.3)^{*}\end{array}$ & $\begin{array}{l}14.9( \pm 0.5)^{*} \\
14.6( \pm 0.4)^{*} \\
14.1( \pm 0.3)^{*}\end{array}$ & $\begin{array}{l}15.5( \pm 0.6)^{\star} \\
14.9( \pm 0.4)^{\star} \\
14.5( \pm 0.5)^{\star}\end{array}$ \\
\hline $\operatorname{TPP}(\mathrm{g} / \mathrm{d} l)^{\mathrm{c}}$ & $\begin{array}{l}14 \\
24 \\
34\end{array}$ & $\begin{array}{l}61.2( \pm 1.8) \\
65.6( \pm 1.1) \\
62.3( \pm 1.2)\end{array}$ & $\begin{array}{l}59.4( \pm 1.7) \\
62.2( \pm 0.8)^{\star} \\
60.2( \pm 1.0)^{\star}\end{array}$ & $\begin{array}{l}59.2( \pm 1.7) \\
61.3( \pm 0.9)^{*} \\
59.4( \pm 0.7)^{*}\end{array}$ & $\begin{array}{l}59.4( \pm 1.2) \\
61.4( \pm 1.1)^{\star} \\
59.1( \pm 0.7)^{\star}\end{array}$ \\
\hline $\mathrm{HT}(\ell /)^{d}$ & $\begin{array}{l}14 \\
24 \\
34\end{array}$ & $\begin{array}{l}0.32( \pm 0.01) \\
0.31( \pm 0.01) \\
0.31( \pm 0.01)\end{array}$ & $\begin{array}{l}0.28( \pm 0.01)^{*} \\
0.26( \pm 0.01)^{*} \\
0.26( \pm 0.01)^{*}\end{array}$ & $\begin{array}{l}0.26( \pm 0.01)^{*} \\
0.26( \pm 0.01)^{*} \\
0.25( \pm 0.01)^{*}\end{array}$ & $\begin{array}{l}0.27( \pm 0.01)^{*} \\
0.26( \pm 0.01)^{*} \\
0.26( \pm 0.01)^{*}\end{array}$ \\
\hline $\operatorname{MCV}(f / \ell)^{e}$ & $\begin{array}{l}14 \\
24 \\
34\end{array}$ & $\begin{array}{l}17.2( \pm 0.2) \\
16.9( \pm 0.2) \\
17.1( \pm 0.2)\end{array}$ & $\begin{array}{l}16.9( \pm 0.2)^{*} \\
16.7( \pm 0.2)^{*} \\
16.8( \pm 0.2)^{*}\end{array}$ & $\begin{array}{l}16.9( \pm 0.2)^{*} \\
16.5( \pm 0.2)^{*} \\
16.7( \pm 0.2)^{*}\end{array}$ & $\begin{array}{l}17.0( \pm 0.2)^{\star} \\
16.5( \pm 0.2)^{\star} \\
16.7( \pm 0.2)^{\star}\end{array}$ \\
\hline $\mathrm{MCHC}(\mathrm{g} / \mathrm{d} \ell \text { cells })^{\dagger}$ & $\begin{array}{l}14 \\
24 \\
34\end{array}$ & $\begin{array}{l}33.3( \pm 0.6) \\
32.8( \pm 0.6) \\
33.5( \pm 1.0)\end{array}$ & $\begin{array}{l}33.8( \pm 0.3) \\
33.3( \pm 1.0) \\
34.0( \pm 0.6)\end{array}$ & $\begin{array}{l}34.3( \pm 0.5) \\
34.8( \pm 0.7)^{\star} \\
34.0( \pm 0.5)\end{array}$ & $\begin{array}{l}34.8( \pm 0.6)^{\star} \\
35.2( \pm 0.8)^{\star} \\
34.8( \pm 0.8)\end{array}$ \\
\hline WCC $\left(\times 10^{9} / l\right)^{g}$ & $\begin{array}{l}14 \\
24 \\
34\end{array}$ & $\begin{array}{l}18.3( \pm 1.3) \\
18.8( \pm 2.4) \\
16.9( \pm 0.9)\end{array}$ & $\begin{array}{l}15.7( \pm 1.1) \\
16.7( \pm 2.2) \\
13.9( \pm 1.1)^{*}\end{array}$ & $\begin{array}{l}14.0( \pm 1.1)^{*} \\
15.4( \pm 1.9)^{*} \\
13.0( \pm 0.9)^{*}\end{array}$ & $\begin{array}{l}14.1( \pm 1.6)^{\star} \\
16.7( \pm 1.6) \\
13.2( \pm 1.3)^{\star}\end{array}$ \\
\hline
\end{tabular}

*Significantly $(P<0.05)$ different from values at time zero (baseline values).

${ }^{a}$ Haemoglobin concentration; ${ }^{b}$ red blood cell count; ${ }^{\text {C }}$ total plasma protein; ${ }^{d}$ haematocrit; ${ }^{e}$ mean corpuscular volume; ${ }^{f}$ mean corpuscular haemoglobin concentration; ${ }^{g}$ white cell count.

at $45 \mathrm{~min}$ and from then on it started to increase again. However, these changes were not significant. In the $34{ }^{\circ} \mathrm{C}$ environment, the mean rate increased from the baseline of $28.2 \pm 1.5$ breaths $/ \mathrm{min}$ to 40.0 \pm 7.9 at $5 \mathrm{~min}$, then decreased to $16.7 \pm 1.9$ breaths $/ \mathrm{min}$ at $45 \mathrm{~min}$, and then started to rise. Ventilation ratewassignificantly $(\mathrm{P}<$ 0.05 ) lower at $45 \mathrm{~min}$ compared to the rate at $5 \mathrm{~min}$ in this group. In the $14{ }^{\circ} \mathrm{C}$ environment, mean rate declined from baseline at $31.7 \pm 1.9$ to reach a minimum of $15.7 \pm 2.4$ at 30 . The mean ventilation rates in this environment at 30,45 , and 60 min weresignificantly $(P<0.05)$ lower than the baseline value. In all of the environments the ventilation rates remained lower than the baseline values at the end of the 60-min monitoring period. Environmental conditions did not havesignificant effects on the ventilation rate.

The results of the effects of xylazine on the haemocytological variables under the different environmental conditions are shown in Table 1. Xylazine significantly $(P<0.05)$ reduced haemoglobin concentration and mean corpuscular volume 15 min post-xylazine injection until the end of the $60 \mathrm{~min}$ monitoring period in all 3environments. A similar, significant $(P<$ 0.05 ) reduction in total protein over the same period occurred in goats in the 24 and $34{ }^{\circ} \mathrm{C}$ environments, while there was no significant change in total plasma protein in the $14^{\circ} \mathrm{C}$ environment. Significant $(P<0.05)$ reductions in haematocrit and red cell count occurred at 15,30 , and $60 \mathrm{~min}$ post-xylazine injection in all environments. Mean corpuscular haemoglobin concentration increased significantly $(\mathrm{P}<0.05) 30$ and 60 min postxylazine injection at $24^{\circ} \mathrm{C}$, and $60 \mathrm{~min}$ at $14{ }^{\circ} \mathrm{C}$, whereas there was no significant change at $34^{\circ} \mathrm{C}$. Xylazine caused a significant $(P<0.05)$ reduction in thetotal white cell count at $30 \mathrm{~min}$ in the $24^{\circ} \mathrm{C}$ environment, whereas this reduction was significant at 15, 30, and $60 \mathrm{~min}$, and at 30 and 60 min in the 34 and $14{ }^{\circ} \mathrm{C}$ environments respectively. These variables had not re turned to thebaselinevalues by theend of the 60 -min monitoring period. Xylazine caused haemolysis, and this was seen in the plasma of all blood samples drawn within the first $5 \mathrm{~min}$ following its injection. Environmental conditions did not have significant effects on the variables.

\section{DISCUSSION}

Goats are more sensitive to xylazine than sheep, and doses of $0.05 \mathrm{mg} / \mathrm{kg}$ may result in profound sedation for 12 or more hours ${ }^{12}$. The time of onset of sedation, the duration of action, and recovery from xylazinein goats varies, and may beinfluenced by dose and route of administration $^{12,19,28,32,35}$. In this study, xylazine administration to the goats initially caused restlessness characterised by bleating, groaning, grunting and limb movements that lasted for up to $5 \mathrm{~min}$. This phenomenon has not been reported previously. This was followed by a period of calm and the animals remained sedated for 25 to $30 \mathrm{~min}$. Over the same period of sedation, xylazine provided good muscle relaxation. Vocalisation and neck flexing following administration of xylazine in goats has been reported to occur $^{28}$. Signs of sedation following administration of xylazine in goats include lowering of the head and neck, partial drooping of the upper eyelid, protrusion of the nictitating membrane and tongue, muscular incoordination and staggering gait $\mathrm{t}^{35}$. Protrusion of thetongue following administration of xylazine to steers has also been reported ${ }^{34}$. While restrained in lateral recumbency, the goats displayed signs of sedation within 5 min of xylazine administration such as protrusion of the nictitating membrane and tongue, and drooping of the upper eyelids. The duration of sedation lasted for 25 to $30 \mathrm{~min}$ and recovery 68 to $74 \mathrm{~min}$, which is in agreement with previousfindings in the same species ${ }^{19,32}$. It has been shown that heifers injected with xylazine and exposed to heat-stress took significantly longer to rise from recumbency compared to those exposed to thermoneutral environmental conditions, and it 
wassuggested that thiscould bedueto increased sensitivity to xylazine of animals in the heat-stress environment ${ }^{15}$. A similar reaction was not observed in goats in the presentstudy following acuteexposureto similar environmental conditions.

Intravenous injection of xylazine induces profusesalivation in ruminants ${ }^{6}$. In this study xylazine induced salivation, starting as small amounts, which proceeded to become copious. This was in agreement with reports in goats ${ }^{23,28,30,35}$, cattle $^{15,34}$ and donkeys ${ }^{27}$. In the present study, salivation started as early as $5.7 \pm$ $1.4 \mathrm{~min}$ and lasted for as long as $45.7 \pm 2.1$ min, and correlated well with previous findings ${ }^{23,35}$. Salivation after xylazine administration has been attributed to the inability of the goats to swallow during sedation $^{23}$. In this study, there was no significant difference in the duration of salivation in the goats under different environmental conditions, contrary to findingsin heifers. Salivation took longer to subside in heifers subjected to heat stress compared to those exposed to thermoneutral conditions, and it was suggested that heat-stresed animals were more sensitive to xylazine than those in thermoneutral conditions ${ }^{15}$.

Xylazine provided good analgesia of abdominal and thoracic skin but no analgesia was present below the coronet. Xylazine has been reported to provide hardly any to moderate analgesic action in theregion of the distal extremities ${ }^{16,22,27}$. In this study, xylazine provided good analgesia, in agreement with findings in goats ${ }^{1,12,35}$, sheep ${ }^{31}$ and cattle ${ }^{15}$. The analgesic property is probably due its action on the autonomic and central nervous system. Even when it is injected locally, xylazine has a potent analgesic effect ${ }^{22}$. The analgesia provided by xylazine is sometimes not adequate, as someanimals reacted to surgical stimulation, even when supportivelocal or regional analgesia was used in combination with intrave nous xylazine $e^{34}$. Xylazine should be supplemented with some form of effective analgesia whenever a surgical proce dure is to be performed ${ }^{34}$. The analgesia provided by xylazine in goats in this study lasted for up to $44 \mathrm{~min}$, which is longer than the times reported in sheep ${ }^{31}$. Differences in environmental conditions in this study did not have significant effects on duration of analgesia as has been observed in cattle $e^{15}$. The long duration of analgesia could be due to the greater sensitivity to xylazine of goats compared to sheep ${ }^{12}$.

Longer recovery periods, longer duration of salivation and longer duration of analgesia in animals exposed to heat stress as compared to thermoneutral conditions has been attributed to increased sensitivity to xylazine in heat-stressed animals ${ }^{15}$. There is a possibility that hormonal or neural changes develop in heat-stressed animals, whereby their metabolic rate decreases as a result of decreased thyroid hormones, which might alter xylazine kinetic properties ${ }^{43}$. The differences between the results of this study and that of Fayed et al. ${ }^{43}$ are possibly due to study design and or species differences. The heifers were conditioned to their respectiveenvironmental conditions for 35 days beforethestudy, whereas thegoats in this study were acutely exposed to the 3 different sets of environmental conditions without prior conditioning. Thyroid activity following acute exposure of cattle to $1^{\circ} \mathrm{C}$ increases significantly from $36 \mathrm{~h}$ after exposure, whereas it remains depressed at $38^{\circ} \mathrm{C}$ after $60 \mathrm{~h}$ following acute exposure $^{43}$. In this study, the goats were exposed to the different environmental conditions for only $60 \mathrm{~min}$, not long enough to alter thyroid activity and subsequently metabolic rate to effect a change in xylazine kinetic properties.

Urination after administration of xylazine is a common occurrence in goats ${ }^{1,28,30}$. In cattle, increased urine output lastsfor up to $5 \mathrm{~h}$, accompanied by the presence of glucose in the urine and increased urine $\mathrm{pH}$, after administration of xylazine ${ }^{40}$. Not only the quantity of urine, but also the frequency of urination increases after xylazine administration in steers ${ }^{34}$. In this study, polyuria occurred after $21.0 \pm 1.9 \mathrm{~min}$ and also after $69.6 \pm$ $3.4 \mathrm{~min}$. This is in agreement with previous reports in goats ${ }^{1,28}$. Polyuria observed in animals following administration of xylazine is attributed to hyperglycaemia and persists for up to $150 \mathrm{~min}$ in goats ${ }^{28}$. Alternatively, it could be secondary to the effects of xylazine on the formation or release of anti-diuretic hormone $(\mathrm{ADH})^{40}$. Polyuria observed in goats in this study coincided with the period of hyperglycaemia, which started at $15 \mathrm{~min}$ post-xylazineinjection, peaking at $30 \mathrm{~min}$ and persisting to the end of the 60-min monitoring period.

A significant reduction in MAP following administration of xylazine as observed in the present study has also been reported earlier in goats and other species ${ }^{3,9,23}$. The decrease in arterial blood pressure due to xylazine in goats is dose-related, and the magnitude of decrease in blood pressure depends on theroute of administration of the drug ${ }^{23}$. Following intramuscular administration, xylazine may not significantly alter blood pressure despite the higher dose used ${ }^{40}$, but greater responses in arterial blood pressure are achieved when the intravenous route is used, despitethe smaller doses injected ${ }^{23}$. Intravenous administration of xylazine in this study resulted in an initial transient increase in MAP in all 3 environments. This phenomenon also occurs in sheep ${ }^{9}$ and calves ${ }^{3}$. Following intravenous administration, $\alpha_{2}$-agonists typically produce an initial rise in arterial blood pressure followed by asustained decrease ${ }^{8}$. Theinitial short-lived pressor response has been reported to occur due to stimulation of the peripheral arterial postjunctional $\alpha_{1}$ and $\alpha_{2}$ adrenoceptors. The sustained hypotensiveresponsehas been attributed to central $\alpha_{2}$ adrenoceptor stimulation ${ }^{33}$.

Acute environmental changes did not result in significant changes in heart-rate after xylazineadministration in the goats. However, at $14^{\circ} \mathrm{C}$ the mean rate was significantly $(P<0.05)$ lower than baseline values. This could be attributed to hypothermia and decreased metabolic rate. A reduction in heart-rate following intramuscular or intravenous xylazine has been reported in goats $12,23,24,28,32,35$, cattle $e^{7,42}$, sheep ${ }^{4,9}$ and horses ${ }^{11,17}$. Similar effects are seen when the drug is administered epidurally in goats ${ }^{1}$ and cattle $e^{38}$. The reduction in heart-rate in goats is dosedependent ${ }^{23}$ and can remain depressed for up to 24 hours $^{12,28,32}$. In addition to bradycardia, xylazine also caused an AV-block followed by tachycardia. It is not uncommon to have episodes of missed $^{4,5}$ and irregular heart-beats ${ }^{1}$ accompanying bradycardia after xylazine administration in animals. In ponies, intravenous administration of xylazine results in sino-atrial (SA) blocks and transient AV-blocks within the 1st minute of its injection ${ }^{17}$. However, the authors were not certain whether the cause of the SA-block was due to baroreceptor reflex and/or vagotonic effects. It is suggested that xylazine causes a decrease in heartratevia its central and peripheral suppression of the sympathetic system ${ }^{24,33}$, or a physiological response to hypertension ${ }^{10}$. The ability of xylazine to decrease heart-rate has been attributed to the withdrawal of the sympathetic tone, and the direct depressant action on the cardiac pacemaker and conduction tissue $e^{2,4,21,22,37}$.

Xylazine significantly reduced the ventilation rate in goats in the $14{ }^{\circ} \mathrm{C}$ environment compared to baseline rates, but no significant changes in rate could be ascribed to acutechanges in environmental conditions. The above-mentioned decrease might be due to hypothermia and decreased metabolic rate. Xylazine is known to depress the ventilation rate $^{1,4,12,16,20,24,26,28,41}$, which can remain below baseline values for hours following its administration ${ }^{28,32,35}$. When injected epidurally, xylazinecan causea reduction 
in the ventilation rate, and irregular breathing ${ }^{1,38}$. In thisstudy, bradypnoea alternated with tachypnoea, dyspnoea and periodic apnoea followed by regular and deep breathing. This has been re ported previously in goats and other species $^{4,5,23,35}$. Apart from causing reduction in ventilation rate, a concurrent de crease in tidal volume in goats ${ }^{28}$ and sheep ${ }^{4}$ may occur. The effects of xylazine on pulmonary function have been attributed to its central $\alpha_{2}$-adrenoreceptormediated activity, which results in respiratory depression ${ }^{1,32}$.

Xylazineinduced significant changes in haemoglobin concentration, red blood cell count, total white blood cell count, total protein, haematocrit, mean corpuscular volume, and mean corpuscular haemoglobin concentration in the goats in under the different environmental conditions. Theobserved decreasein total number of erythrocytes, leukocytes, haemoglobin concentration ${ }^{12,24}$ and haematocrit ${ }^{12,13,24}$, during the period of sedation following administration of xylazine has been reported in goats and other species. Contrary to other findings in goats ${ }^{24}$, xylazinecaused significant $(\mathrm{P}<$ $0.05)$ reduction in total plasma proteins in the goats exposed to 24 and $34^{\circ} \mathrm{C}$ in this study. The haemolysis observed in plasma of blood samples collected in the first 5 min following injection of xylazine is in agreement with previous reports after propionylpromazineadministration ${ }^{13}$. This lytic effect may contribute to the de cline in packed cell volume ${ }^{13}$. Pooling of blood in the spleen as has been reported with other tranquillisers in goats ${ }^{29}$ can also lead to decrease in red blood cell count, haematocrit and haemoglobin concentration following administration of xylazine hydrochloride. Engorgement of the spleen leads to a reduction in blood components in the peripheral circula tion $^{36}$. The fall can also be attributed to haemodilution caused by an influx of intestinal fluids duein part to the decreased heart-rateand to thelow blood pressure ${ }^{14}$. Thefall in total whitecell count is probably the result of adrenocortical stimulation and the subsequent effect of glucocorticoids on circulating neutrophils and lymphocytes following xylazine injection. Increased adrenocortical activity causes depression of lymphocytic tissue and disappearance of lymphocytes from the peripheral blood ${ }^{36}$.

In conclusion, the administration of xylazine to goats and exposing them to acute changes in environmental conditionsresulted in significant changesin the measured ventilatory and cardiovascular variables, independent of the climatic changes.

\section{ACKNOWLEDGEMENTS}

We would like to thank the Kenya Government, the International Development Association/International Bank for Reconstruction and Development of the World Bank, Bayer - Animal Health Division, South Africa, and the University of Pretoria for their financial and material support.

\section{REFERENCES}

1. Aithal H P, Pratap K, Singh G R 1996 Clinical effects of epidurally administered ketamine and xylazine in goats. Small Ruminant Research 24: 55-64

2. Antonaccio M J, Robson R D, Kerwin L 1973 Evidence for increased vagal tone and enhancement of baroreceptor reflex activity after xylazine in anaesthetized dogs. European Journal of Pharmacology 23: 311-315

3. Aouad I J, Wright M E, Shaner W T 1981 Anaesthesia evaluation of ketamine and xylazine in calves. Bovine Practice 2: 22-31

4. Aziz M A, Carlyle S S 1978 Cardiovascular and respiratory effects of xylazinein sheep. Zentralblatt für Veterinärmedizin Reihe A 25 : 173-180

5. Bafi-Yeboa M, Huvos A 1980 Rompun ${ }^{\circledR}$ in caprine practice. Veterinary M edical Review 1: 61-62

6. Booth N H 1988Non-narcotic analgesics: In Booth N H, McDonald E L (eds) Veterinary pharmacology and therapeutics (6th edn). lowaStateUniversity Press, Ames: 351-362

7. Campbell K B, Klavano P A, Richardson P, Alexander J E 1979Hemodynamic effects of xylazine in the calf. Journal of the A merican Veterinary M edical Association 40: 1777-1780

8. Constantine J W, McShaneW K 1968Analysis of the cardiovascular effects of 2-(2,6-dichlorophenyl-amino)-2-imidazole hydrochloride (catapress). European Journal of Pharmacology 4: 109-117

9. Celly C S, McDonell W N, Young SS, Black W D 1997 The comparative hypoxaemic effect of four $\alpha 2$-adrenoceptor agonists (xylazine, romifidine, detomidine and medetomidine) in sheep. Journal of Veterinary Pharmacology and Therapeutics 20: 464-471

10. Clark D M, Martin R A, Short C A 1982 Cardiopulmonary responses to xylazine/ ketamine anaesthesia in the dog. Journal of the American A nimal H ospital Association 18: 815-821

11. ClarkeK W, Hall L W 1969Xylazine- A new sedativefor horses and cattle. TheVeterinary Record 85: 512-517

12. Dehghani S, Sharifnia N, Yahyaei M P, Souri A 1991 Clinical, haematological and biochemical effects of xylazine, ketamine and their combination in caprine and feline. Proceedings of the 4th International Congress of Veterinary A naesthesia, $\mathrm{U}$ trecht, 25-31August 1991: 129-133

13. DeM oor A, Desmet P 1971 Effect of Rompun ${ }^{\circledR}$ on acid-base-equilibrium and arterial $\mathrm{O}_{2}$ pressure in cattle. Veterinary M edical Review 2: 163-169

14. Drevemo S, Karstad L 1974 The effect of xylazine and xylazine-etorphine-acepromazine combination on some clinical and haematological parameters in impala and eland. J ournal of WildlifeD iseases 10: 377-383

15. Fayed H A, Abdalla B E, Anderson R R, Spencer K, Johnson D H 1989 Effect of xylazine in heifers under thermoneutral or heat stress conditions. American Journal of Veterinary Research 50: 151-153

16. Fessl L 1970Clinical experiencewith Bay Va 1470 (Rompun $\left.{ }^{\circledR}\right)$. Veterinary M edical R eview 70(3): 199-210

17. Garner H E, Amend J F, Rosborough J P 1971 Effects of Bay Va 1470 on cardiovascular parameters in ponies. Veterinary $M$ edicine and Small A nimal Clinician 66: 1016-1021

18. Greene SA, Thurmon J C 1988 Xylazine - a review of its pharmacology and use in veterinary medicine. Journal of Veterinary Pharmacology and Therapeutics 11: 295-313

19. Keller G L, Bauman D H 1978Ketamineand xylazine anaesthesia in the goat. Veterinary $M$ edicine and the Small Animal Clinician S73: 443-444

20. Kerr D D, Holbert D, Huggins K 1972 Comparison of the effects of xylazineand acetylpromazine maleate in the horse. A merican Journal of Veterinary Research 33: 777-784

21. KlideA M, Calderwood H W, Soma R L 1975 Cardiopulmonary effects of xylazine in dogs. American Journal of Veterinary R esearch 36: 931-935

22. Knight A P 1980 Xylazine. Journal of the A merican Veterinary M edical Association 176: 454-455

23. Kokkonen U M, Eriksson L 1987 Cardiovascular and allied actions of xylazine and atropine in the unanaesthetized goat. Journal of Veterinary Pharmacology and Therapeutics 10: 11-16

24. Kumar A, Thurmon J C 1979 Cardiopulmonary, hemocytologic and biochemical effects of xylazine in goats. Laboratory A nimal Science 29: 486-491

25. Magdub A, Johnson H D, Belyea R L 1982 Effects of environmental heat and dietary fibre on thyroid physiology of lactating cows. Journal of D airy Science 65: 2323-2331

26. McCashin F B, Gabel A A 1975Evaluation of xylazine as a sedative and pre-anaesthetic agent in horses. A merican Journal of Veterinary Research 36: 1421-1429

27. Mogoa E G M 1990 Use of xylazine hydrochloride, ketaminehydrochloride and atropine sulphate for anaesthesia in donkeys. MSc thesis, University of Nairobi

28. Mohammed A, Yelwa H A 1993 Effect of xylazine hydrochloride $\left(\right.$ Rompun ${ }^{\circledR}$ ) on Sokoto red goats. Small Ruminant Research 12: 107-113

29. Monzaly M El-M, El-Amrousi S, El-Gindi M H 1972 Some aspects of tranquilization and anaesthetization in the goat. Zentralblatt für Veterinärmedizin Reihe A 19: 219-228

30. Neophytou C 1982 The use of Rompun ${ }^{\circledR}$ in Damascusgoats. A field report from Cyprus. Veterinary M edical Review 2: 216-219

31. O`Hair K C, McNeil J S, Phillips J J 1986 Effects of xylazinein adult sheep. Laboratory A nimal Science 36: 563

32. Prajapathi A K, Jani B M, Mehta V M 1994 Clinical and physiological effects of different intramuscular dosages of xylazine in goats. Indian Veterinary Journal 71: 607-609

33. Ruffolo R R, Nichols A J, Stadel M, Hieble J H 1993 Pharmacologic and therapeutic applications of $\alpha_{2}$-adrenergic receptor subtypes. Annual Review of Pharmacology and Toxicology 32: 243-279

34. Raptopoulos D, Weaver B M Q 1984 Observations following intravenous xylazine administration in steers. The Veterinary Record 114: $567-569$

35. Saleh A S 1993 Antagonistic effect of Doxapram after Rompun ${ }^{\circledR}$ treatment with 
special reference to acid-base balance in goats. Assiut Veterinary M edical Journal 29: 208-214

36. SchalmW O 1965Veterinary hematology (2nd edn). Lea and Febiger, Philadelphia

37. Schmitt H, Fournadjiev G, Schmitt H 1970 Central and peripheral effects of Bayer 1470 on the sympathetic system. European Journal of Pharmacology 10: 230-238

38. Skarda R T, Muir W W 1992 Physiologic responses after caudal epidural administration of detomidinein horses and xylazinein cattle. In Short C E van Posnak A (eds) A nimal pain. Churchill Livingstone, New York: 292-302

39. Skeggs L T, Hochstrasser H 1964 Multiple automatic sequential analysis. Clinical Chemistry 10: 918-936

40. Thurmon J C, Nelson D R, Hartsfield S M, RumoreC A 1978Effects of xylazine hydrochloride on urine in cattle. Australian Veterinary Journal 54: 178-180

41. White R S, Bali S, Bark H 1987 Xylazineand ketamine anaesthesia in the Dromedary camel under field conditions. TheVeterinary Record 120: 110-113

42. Young P L 1979The effect of xylazineon the body temperature of cattle. A ustralian Veterinary Journal 55: 442-443

43. Yousef M K, Kibler H H, Johnson D H 1967 Thyroid activity and heat production in cattle following sudden ambient temperature changes. Journal of A nimal Science 26: 142-148 